\title{
Description of the AQEM/STAR invertebrate database
}

Astrid Schmidt-Kloiber, Jörg Strackbein, Robert Vogl, Mike T. Furse \& Daniel Hering
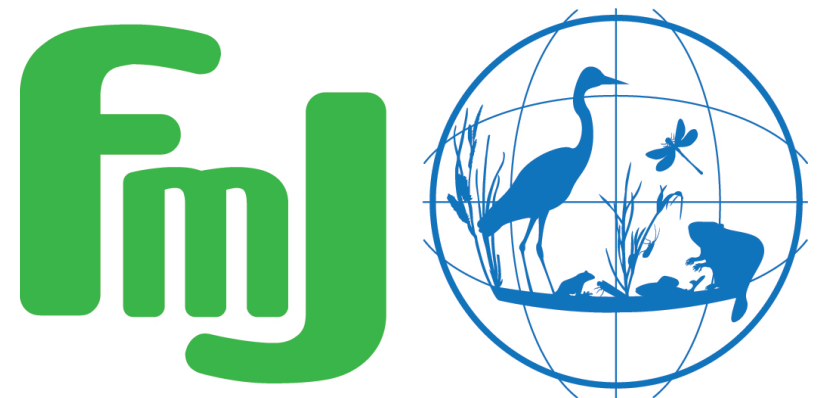

Freshwater Metadata Journal 



\title{
Description of the AQEM/STAR invertebrate database
}

\author{
Astrid Schmidt-Kloiber ${ }^{1}$, Jörg Strackbein ${ }^{2}$, Robert Vogl ${ }^{1}$, Mike T. Furse ${ }^{3}$ \& Daniel Hering ${ }^{2}$ \\ 1 BOKU - University of Natural Resources \& Life Sciences, Vienna, Austria; corresponding author: astrid.schmidt-kloiber@boku.ac.at \\ 2 UDE - University of Duisburg-Essen, Essen, Germany \\ $3 \mathrm{CEH}$ - Centre for Ecology \& Hydrology, Dorset, United Kingdom
}

Please cite this paper as follows: Schmidt-Kloiber A., Strackbein J., Vogl R., Furse M.T. \& Hering D., 2014. Description of the AQEM/STAR invertebrate database. Freshwater Metadata Journal 2: 1-8.

http://dx.doi.org/10.15504/fmj.2014.2

Received: 2014-10-08 / Published: 2014-10-08

\section{Keywords}

macro-invertebrates, assessment, Europe, Water Framework Directive, environmental parameters, EU projects, AQEM, STAR

\section{Short description of the dataset/summary}

This database contains the macro-invertebrate data that were collected during the AQEM and STAR projects. Samples were taken in 14 European countries using the multi-habitat-sampling (MHS) method as well as the RIVPACS methodology for selected sites. Taxa were identified to the most precise achievable level. Additionally the database contains information on hydromorphology and environmental parameters. The latter include stressor gradients along which the samples were taken. Supplementary fish, macrophyte and diatom data from the STAR project are separately available and can be linked to the invertebrate database. The AQEM and STAR projects were funded by the EU 5th Framework Programme (FP5).

\section{General information}

dataset entry ID:

name of the dataset:

full name of the dataset:

type of dataset:

data type:
science keywords according to GCMD:

topic:

ISO topic category according to ISO 19115:

AQEM/STAR invertebrate database

species (taxonomic group) per site database including environmental information

point data/observation data

Biota, Inland Waters 


\section{Technical and administrative specifications}

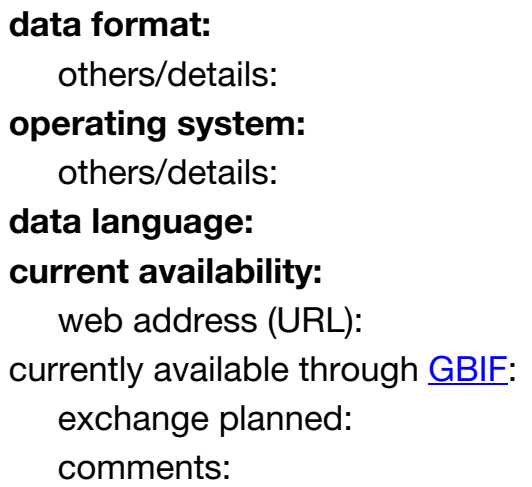

yes

online internet (HTTP), e-mail

www.eu-star.at

free

Astrid Schmidt-Kloiber

0043-1-47654-5225

astrid.schmidt-kloiber@boku.ac.at

Max Emanuel Straße 17

1180 Vienna

Austria

Joerg Strackbein

0049-201-183-4993

joerg.strackbein@uni-due.de

University of Duisburg-Essen

Universitätsstrasse 5

45141 Essen

Germany

Daniel Hering

daniel.hering@uni-due.de
Access

Access 97/2000

Win XP

all Windows systems possible

English

restricted access, internal

www.eu-star.at

no

no

Access currently for STAR/AQEM consortium only; please contact the responsible persons for other options.

Different extracts of the database are available as Excel files: abiotic data, adjusted taxalists, combinations of river types per ecoregion, shape files for sample points, etc.

completed

internal description

German

Data can be sent by mail or downloaded from eu-star.at after access granted.

BOKU - University of Natural Resources \& Life Sciences

http://www.wau.boku.ac.at/en/ihg

https://www.uni-due.de/aquatic_ecology 


\section{Intellectual property rights and citation}

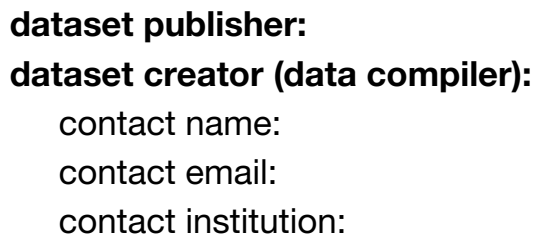

title:

year:

comments:

single

2005

2014 1-20.

2004 3-29.

2006 not published yet

AQEM and STAR project partners and the EU joerg.strackbein@uni-due.de University of Duisburg-Essen

Data provider must be informed of publication 45 days in advance and can object to the use of the dataset within 30 days. Data must be publicly acknowledged and cited correctly.

AQEM and STAR consortia

AQEM and STAR macro-invertebrate database.

Schmidt-Kloiber A., Strackbein J., Vogl R., Furse M.T. \& Hering D.

Description of the AQEM/STAR invertebrate database

http://dx.doi.org/10.15504/fmj.2014.2

Hering, D., Moog, O., Sandin, L. \& Verdonschot, P.F.M.

Overview and application of the AQEM assessment system. Hydrobiologia 516,

Furse, M.T., Hering, D., Moog, O., Verdonschot, P.F.M., Sandin, L., Brabec, K., Gritzalis, K., Buffagni, A., Pinto, P., Friberg, N., Murray-Bligh, J., Kokes, J., Alber, R., Usseglio-Polatera, P., Haase, P., Sweeting, R., Bis, B., Szoszkiewicz, K., Soszka, H., Springe, G., Sporka, F. \& Krno, I.

The STAR project: context, objectives and approaches. Hydrobiologia 566,

The database was collated and is owned by AQEM and STAR project partners and the EU (in total 22 partners).

\section{General data specifications}

regional coverage of the dataset: scale of the dataset:

continental

\section{spatial extend (bounding coordinates):}

southernmost latitude $\left[^{\circ}\right]$ :

35

northernmost latitude $\left[^{\circ}\right]$ :

60

westernmost longitude $\left[{ }^{\circ}\right.$ :

$-8$

easternmost longitude $\left[{ }^{\circ}\right]$ :

26

minimum altitude:

1 metres

maximum altitude:

1820 metres

countries: 
Latvia, Netherlands, Poland, Portugal, Slovakia, Sweden, United Kingdom

European ecoregions according to Illies (WFD):

Iberic-Macaronesian Region (ER1), Italy, Corsica and Malta (ER3), Alps (ER4), Hellenic Western Balkan (ER6), Eastern Balkan (ER7), Western Highlands (ER8), Central Highlands (ER9), The Carpathians (ER10), Central Plains (ER14), Baltic Province (ER15), Eastern Plains (ER16), Great Britain (ER18), Fenno-Scandian Shield (ER22)

ecosystem type: rivers

covered timeframe:

$2000-2004$

\section{Site specifications}

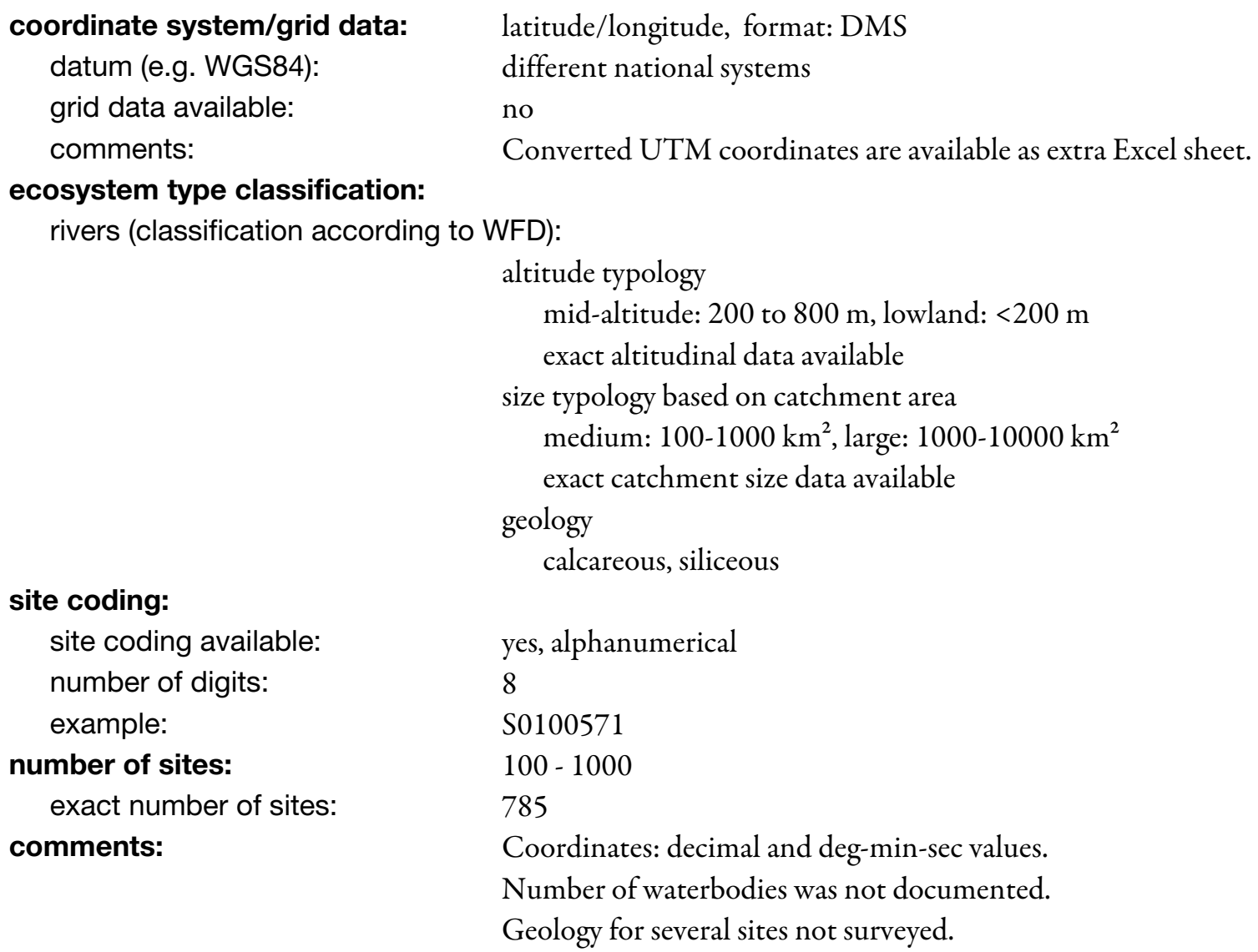

\section{Climate and environmental data}

\section{climate related data:}

available parameters per site:

$$
\begin{aligned}
& \text { mean discharge } \\
& \text { data source: depends on country }
\end{aligned}
$$

\section{environmental data:}

available parameters per catchment:

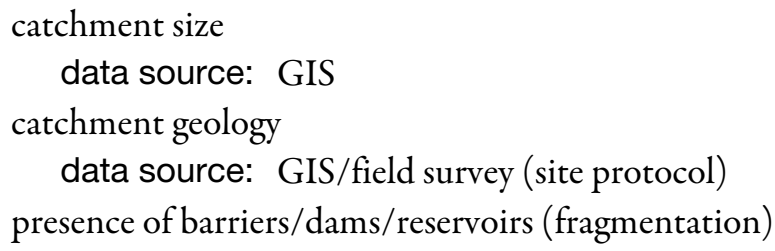


available parameters per site:

physico-chemistry data:

stressors influencing the sites: reference sites available: data source: GIS/field survey (site protocol)

catchment land use upstream of sampling site data source: GIS, field survey (site protocol)

information on riparian vegetation (incl. information on modification)

data source: field survey (site protocol)

information on embankment (incl. information on modification) data source: field survey (site protocol)

information on channel form (incl. information on modification) data source: field survey (site protocol)

information on cross section (incl. information on modification) data source: GIS, field survey (site protocol)

information on water uses (e.g., irrigation, fish ponds)

data source: GIS, field survey (site protocol)

distance to next migration barrier upstream data source: GIS, field survey (site protocol)

distance to next migration barrier downstream data source: GIS, field survey (site protocol)

river length data source: GIS

distance to source data source: GIS

stream order (according to Strahler) data source: GIS, other slope

data source: GIS, field survey (site protocol)

altitude

data source: GIS, field survey (site protocol)

discharge

data source: field survey (site protocol)

current velocity

data source: field survey (site protocol)

maximum depth

data source: field survey (site protocol)

mean depth

data source: field survey (site protocol)

substrate composition

data source: field survey (site protocol)

total $\mathrm{P}$, ortho $\mathrm{P}$, nitrate, nitrite, ammonium, hardness, alkalinity, oxygen

content, BOD5 (biochemical oyxgen demand), pH, conductivity, chlorophyll, colour, substrate

yes 


\begin{tabular}{|c|c|c|c|c|}
\hline stressor & $\begin{array}{l}\text { restored sites } \\
\text { available }\end{array}$ & $\begin{array}{l}\text { data before/after } \\
\text { restoration } \\
\text { available }\end{array}$ & $\begin{array}{l}\text { stressor gradient } \\
\text { available }\end{array}$ & comments \\
\hline $\begin{array}{l}\text { hydromorphological } \\
\text { degradation }\end{array}$ & no & no & & $\begin{array}{l}\text { parameters of the STAR site } \\
\text { protocol used for gradient } \\
\text { classification }\end{array}$ \\
\hline acidification & no & no & & $\begin{array}{l}\text { parameters of the STAR site } \\
\text { protocol used for gradient } \\
\text { classification }\end{array}$ \\
\hline organic pollution & no & no & & $\begin{array}{l}\text { parameters of the STAR site } \\
\text { protocol used for gradient } \\
\text { classification }\end{array}$ \\
\hline general degradation & no & no & & $\begin{array}{l}\text { parameters of the STAR site } \\
\text { protocol used for gradient } \\
\text { classification }\end{array}$ \\
\hline
\end{tabular}

\section{Biological data}

biological data origin:

specify project:

organism group addressed:

comments: from sampling

AQEM and STAR, EU FP5 funded projects

macro-invertebrates (Mollusca, Crayfish, Ephemeroptera, Odonata, Plecoptera,

Trichoptera, Chironomidae)

Fish data are stored in the EFI+ database, which is linked to this database.

Macrophyte and diatom data are also available. Replicate samples are included.

\section{Sample specifications/sample resolution}

\section{macro-invertebrates:}

\section{sample information:}

covered timeframe:

$2000-2003$

historical data:

no

palaeo data:

no

season:

spring, summer, autumn, winter

temporal resolution/frequency of sampling:

time series data:

per season

comments:

no

\section{taxonomic resolution:}

level:

Identification to the most precise achievable level; identification level depends on the country and on the taxonomic group.

other taxonomic levels:

percentage of species level data:

genus, species, other

higher than genus level $20 \%$

55

AQEM/Star

Schmidt-Kloiber, A., Graf, W., Lorenz, A., Moog, O. (2006): The

AQEM/STAR taxalist - a pan-European macro-invertebrate ecological database and taxa inventory. Hydrobiologia 566, 325-342.

ID_AQEM, DV, TCM, Perla, shortcode, Furse code 


\section{sample specifications:}

$\begin{array}{ll}\text { type: } & \text { quantitative (abundance data) } \\ \text { replicate samples: } & \text { yes } \\ \text { number of samples: } & 260\end{array}$

specification of method(s) used for sampling and sorting:

Multi-Habitat-Sampling (MHS), RIVPACS sampling

reference(s): $\quad$ Hering, D., Buffagni, A., Moog, O., Sandin, L., Sommerhäuser, M., Stubauer, I. Feld, C.K., Johnson, R., Skoulikidis, N., Verdonschot, P.F.M. \& Zarádková, S. (2003): The development of a system to assess the ecological quality of streams based on macroinvertebrates - design of the sampling programme within the AQEM project. International Review of Hydrobiology 88, 345-361.

Wright, J.F., Sutcliffe, D.W. \& Furse, M.T. (eds) (2000): Assessing the biological quality of fresh waters: RIVPACS and other techniques, published by the Freshwater Biological Association, Ambleside, ISBN 978-0900386-62-6.

sample type (e.g. habitat specific samples, composite samples etc.):

composite samples

specific sample location (e.g. littoral, profundal, transect, shoreline, hyporheic zone, etc.):

Number and location of the individual samples based on the proportional cover of substrates at the sampling site.

\section{Other specifications}

GIS layers, shapes related to the dataset:

no data available

availability of photos:

yes

availability of maps: yes

quality control procedures:

Were any quality control procedures applied to your dataset?

yes

quality control protocols and comments:

Complete invertebrate samples and difficult to identify specimens were sent between project partners and cross-checked, site protocol data were entered and quality checked, taxonomic adjustments were made, raw and adjusted taxa lists are available

comments: General information: www.aqem.de and www.eu-star.at. The projects were funded under FP5, contract numbers and EVK1-CT1999-00027 and EVK1-CT 2001-00089.

\section{Acknowledgements}

We thank all the participating partners for their work in providing these data. AQEM was funded under EVK1-CT1999-00027 and STAR under EVK1-CT 2001-00089. 


\section{References}

Furse, M.T., Hering, D., Moog, O., Verdonschot, P.F.M., Sandin, L., Brabec, K., Gritzalis, K., Buffagni, A., Pinto, P., Friberg, N., Murray-Bligh, J., Kokes, J., Alber, R., Usseglio-Polatera, P., Haase, P., Sweeting, R., Bis, B., Szoszkiewicz, K., Soszka, H., Springe, G., Sporka, F. \& Krno, I., 2006. The STAR project: context, objectives and approaches. Hydrobiologia 566, 3-29. http://dx.doi.org/10.1007/s10750-006-0067-6

Hering, D., Buffagni, A., Moog, O., Sandin, L., Sommerhäuser, M., Stubauer, I., Feld, C., Johnson, R., Pinto, P., Skoulikidis, N., Verdonschot, P. \& Zahrádková, S., 2003. The development of a system to assess the ecological quality of streams based on macroinvertebrates - design of the sampling programme within the AQEM project. International Review of Hydrobiology 88, 345-361. http://dx.doi.org/10.1002/iroh.200390030

Hering, D., Moog, O., Sandin, L. \& Verdonschot, P.F.M., 2004. Overview and application of the AQEM assessment system. Hydrobiologia 516, 1-20. http://dx.doi.org/10.1023/B:HYDR.0000025255.70009.a5

Schmidt-Kloiber, A., Graf, W., Lorenz, A. \& Moog O., 2006. The AQEM/STAR taxalist - a pan-European macro-invertebrate ecological database and taxa inventory. Hydrobiologia 566, 325-342.

http://dx.doi.org/10.1007/s10750-006-0086-3

Wright, J.F., Sutcliffe, D.W. \& Furse, M.T. (eds), 2000. Assessing the biological quality of fresh waters: RIVPACS and other techniques, published by the Freshwater Biological Association, Ambleside, ISBN 978-0900386-62-6. 